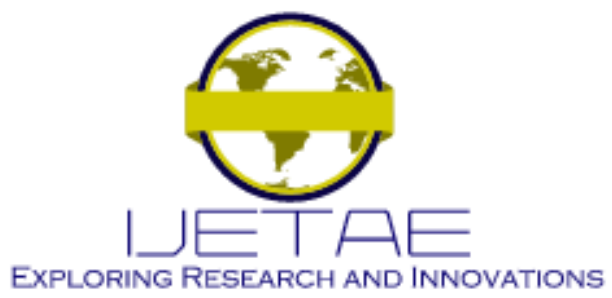

International Journal of Emerging Technology and Advanced Engineering

Website: www.ijetae.com (E-ISSN 2250-2459, Scopus Indexed, ISO 9001:2008 Certified Journal, Volume 11, Issue 06, June 2021)

Manuscript Received: 04 April 2021, Received in Revised form: 10 May 2021, Accepted: 13 June 2021

DOI: 10.46338/ijetae0621_08

\title{
Reporting Key Performance Indicator for Driver Using Whatsapp
}

\author{
Rintis Mardika Sunarto ${ }^{1}$, Abba Suganda Girsang ${ }^{2}$, Melva Hermayanty Saragih ${ }^{3}$ \\ ${ }^{1,2}$ Computer Science Department, BINUS Graduate Program-Master of Computer Science, Bina Nusantara University, Jakarta, \\ Indonesia 11480 \\ ${ }^{3}$ Management Department, BINUS Business School Undergraduate Program, Bina Nusantara University, Jakarta, \\ Indonesia 11480
}

\begin{abstract}
Employee performance is very important at the company, because employees are the main assets of the company, many companies pay less attention to this, even though this is closely related to customer satisfaction in service and company policy to determine the employee's future. PT. XYZ is a company that provides organized professional services and strict recruitment principles, even before starting work for drivers it must do training for 3 days. However, the facts in the field are different, there are still customers who complain because of poor driver's obligations, such as arriving late or not being good. Because there is no application yet to assess performance, this causes companies to collect complaints data and conduct performance evaluations based on facts in the field in real time. With this problem, the whatsapp chat application is chosen as media reporting, because according to the statistics of active media users, whatsapp will make it easier for drivers and customers to connect with the company's customer service (ChatBOT) in real time. The purpose of this study is to create and manage Key Performance Indicators by getting data feedback from the driver or customer per day that will be obtained at the end of the monthly period. Data obtained from feedback will be given to customers who provide material for companies to make decisions to determine work contracts and awards for drivers who work well.
\end{abstract}

Keywords - Key Performance Indicator, Whatsapp, Chatbot, Report, Driver, Whatsapp Gateway.

\section{INTRODUCTION}

Social media is media on the internet that allows users to present themselves or interact, facilitate, share, communicate with other users, and create social bonds virtually [1]. The development of social media in the world is getting more advanced. Where social media such as whatsapp, telegram, and line open documentation to developers to create artificial intelligence with instant messages or what we often hear Chatbot.
ALICE Bot is a chat bot using artificial intelligence markup language (AIML). It is used for response the customer's questions [2].

Recently, natural language processing (NLP) approach is used for developing chatbot such as Veronika, Aichat and Botika [3]. Nowadays social media has touched various aspects of business with artificial intelligence to provide customer convenience. Many business people who have developed artificial intelligence using several social media such as WhatsApp or Telegram for customer service needs, this is quite effective in developing their business because of the large number of active users. Some research about use of smartphone to increase employee performance and increases home-work disruption [4][5]. One of the contributors in used of smartphone is messaging services and Voice over IP (VoIP) such as Whatsapp [6][7]. Whatspp is one most popular used in Indonesia people.

Referring to the data, with the number of active users because of whatsapp the user sector, then with social media accompanied by artificial intelligence can be a solution to various company problems, this is related to the effectiveness in customer service can reduce the burden on the company in interacting with customers because everything becomes automatic and data obtained from customers can be processed in such a way as to the system for the needs of the company.

PT. XYZ is a company that provides professional driver services that are organized and with strict recruitment principles, but the process of evaluating the performance of drivers who have done their job is currently not going well, is still done semi-manually. The problem that often occurs so far is the unavailability of central customer service to serve reports in real-time, even though this is very influential on the driver KPI. Currently, Key Performance Indicators (KPI) is also used for controlling and planning to support decision makers [8]. 


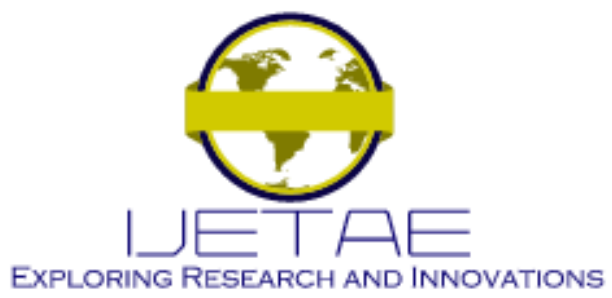

International Journal of Emerging Technology and Advanced Engineering

Website: www.ijetae.com (E-ISSN 2250-2459, Scopus Indexed, ISO 9001:2008 Certified Journal, Volume 11, Issue 06, June 2021)

From some previous studies relating to the use of instant messaging is quite effective to support system requirements that are not too large for example in PLO User Interface Based On Telegram research [9], but according to the authors the drawback is that Telegram is rarely used by the general public especially in this study is the Driver and Client at PT. XYZ

The influence or impact resulting from the development of a Whatsapp-based Customer and Attendance Driver Real Time Report System is an automatic performance review commonly called a KPI (key performance indicator) on the driver. PT. XYZ will conduct a driver performance review and review every month. The assessment will affect the extension of the driver contract that has been accumulated for one month based on data that has been entered for one month through the Whatsapp-based Customer and Attendance Driver Real Time Report System. KPIs that measure activities that have a significant effect on future performance, which are the root causes of the results (ie lagging indicators) that they influence, and can be followed up for future performance on one or more lagging indicators [10].

\section{RELATED WORKS}

\section{A. Key Performance Indicator}

Key Performance Indicator is a measurement that assesses how an organization executes its strategic vision [11]. Key Performance Indicators are quantitative and gradual for the company and have various perspectives and are based on concrete data and are the starting point for setting goals and formulating organizational strategies [12].

KPI or key performance indicators are defined as Indicators or measures that provide information on success to realize the strategic goals that have been set. In preparing KPI, it is necessary to stipulate clear, specific and measurable performance indicators. Determination of the assessment numbers using SMART criteria or abbreviations of:

a. Specific: targets that are specific, detailed and focused.

b. Measurable: assessment that can be measured.

c. Achievable: realistic and attainable targets.

d. Relevant: targets in accordance with relevant aspects related to the main task.

e. Time: time to reach the target / deadline.
Research on KPIs has been carried out by developing a group of key strategic performance indicators (KPI) to monitor and improve the performance of tertiary care hospitals, including various services. This research proposed fifty eight parts which converts into ten categories KPI . This KPI. This KPIs selected manual and subject to experiences of each members employee [13].

Examples of KPI implementation in the application are the KPI applications using the Balance Score Card approach, this application will receive input data from management which will then be processed with a formula so as to produce an achievement score which will then be compared with the achievement target at both the indicator level and the division level [14].

\section{B. Chatbot}

Some researches related to Chatbot have been conducted. Travis proposed Telegram Bot which is able to send special keyboard to explore information in system [15]. The another research proposed connecting some users with online order such as OpenTable and Uber [16]. Abeshav et al [17] proposed a chat bot for health service. The system is built integrating cellular health and cellular message carriers. It used for replace service is based on email [17].

Prastowo et al [9] conducted the research which integrates Telegram bot with PLO. The results shows that bot increase the quality of communication between user. Since this communication increases the huge data server, this researcher also construct the bot efficiency [9]. The telegram bot can be used as an access interface to the PLO system. Multithread PLO can be accessed through a reply mechanism. Security to access PLO through bots is guaranteed because chatID is unique for each bot user. However, the more messages sent by the bot, the greater the delay will occur, and thus will disrupt PLO desktop operations [9].

Chatbot research also exists by using Natural Language and AI using NLTK tools, NLTK is written in Python and distributed under the open source GPL license. It was concluded that Chatbot uses NLP and heuristic methods such as pattern matching and functionality are more realistic than one approach method. A very general response can be achieved. These problems will be solved by statistical models by inducing real emotional content and varied responses. 


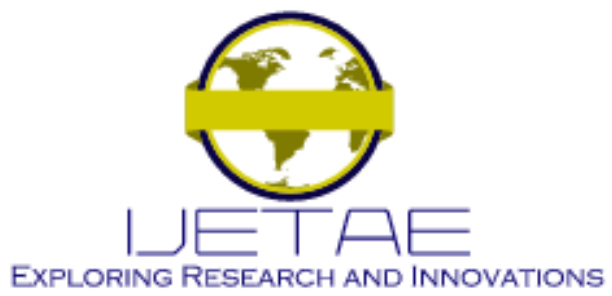

International Journal of Emerging Technology and Advanced Engineering

Website: www.ijetae.com (E-ISSN 2250-2459, Scopus Indexed, ISO 9001:2008 Certified Journal, Volume 11, Issue 06, June 2021)

This research has presented generally for autoresponders for WhatsApp chat messages using the Chatterbot python. And Chatterbot has the ability of machine learning algorithms to produce various types of responses. This makes it easy for developers to create chat bots and automate conversations with users [18].

\section{PROPOSED METHOD}

This research methodology is applied directly to the system that has been used at PT. XYZ, and done as follows:

1. Formulate the message format

2. Designing a system to access Whatsapp Bot

3. Develop a model of message replies

4. Observe user behavior

5. Analyzing KPIs based on data obtained from the user

This Chatbot development does not change the way the system works, here the author uses a Webhook that is placed on the PT. XYZ server. The author chooses WebHook based on real time communication. Information flow from PT. XYZ to users via Whatsapp Bot or vice versa is illustrated in figure 1.

This bot was developed with the PHP programming language with the Laravel framework. PHP is a server-side script programming language that is interpreted to be constantly updated [19]. The bot will invoke the API provided by a third party server that is connected to the Whatsapp server. The bot will also call the API that accesses the PT system. The previous XYZ has been developed.

Mockup system design which has been approved by PT. $\mathrm{XYZ}$ and prototypes will be used to determine:

A. Framework used on the system.

B. Functions on the system in accordance with the design of the system processes that have been made and the need to overcome the problems that occur at PT. XYZ.

C. The results of making this system can affect the KPIs (Key Performance Indicator) of drivers from PT. XYZ

By making a prototype it will facilitate the system development stage in accordance with the needs so that it can meet the needs and solve problems at PT. XYZ. If the prototype has not been made or not in accordance with the needs of the system that is currently running, a redesign process will be carried out to achieve the goal of the system.

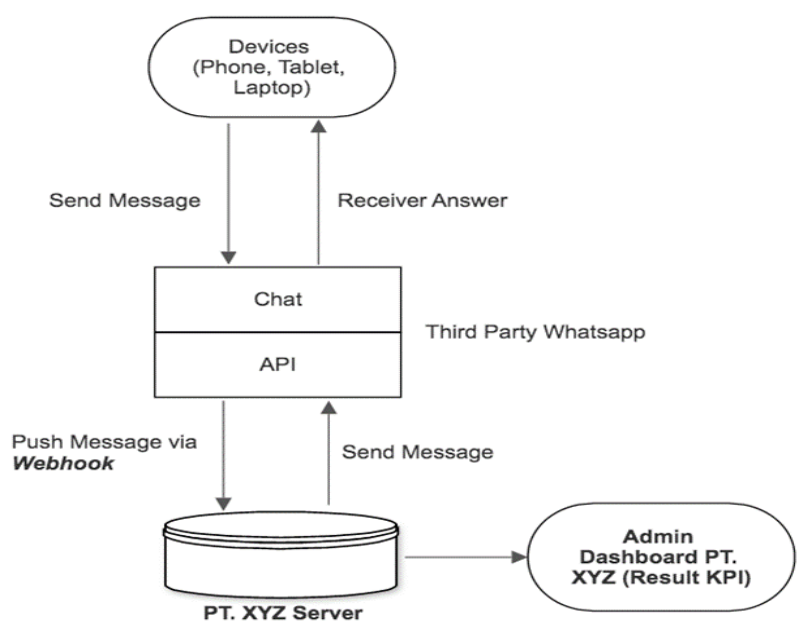

Figure 1 Information Flow

\section{ANALYSIS PERFORMANCE}

\section{A. System Design and Activity}

To interact with the Bot, at the beginning the user only needs to send a "/ hello" message, the system will check if the user's Whatsapp number is on the PT. XYZ system. In this case all data has been integrated with the PT. XYZ system. So the Bot can directly interact in accordance with existing data. If the Whatsapp number does not match, the Bot will not interact further, but if the Whatsapp number is on the PT. XYZ system. Then Bot will send a reply message and the user can interact further with the PT. XYZ system. By writing a message and receiving a message, for example by sending a message or sub comment "/ absent" or typing the number " 1 ", the bot will reply according to what the user needs.

There are four activities that can be done by the bot system, namely verification of numbers, receiving messages, sending messages and reading old messages. In the system of PT. XYZ, bot activity as a user interface involves 4 communication agents, that is:

1. System users in the Web Browser. The target users in the Web Browser are staff of PT. XYZ, which is the HRD and Finance department. 


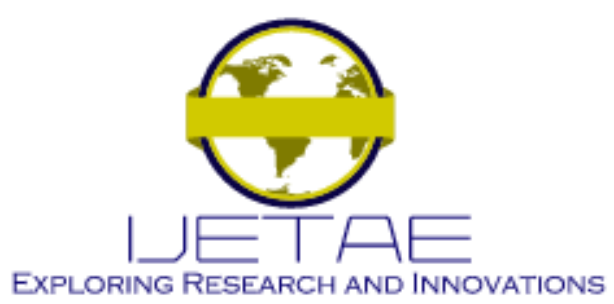

International Journal of Emerging Technology and Advanced Engineering Website: www.ijetae.com (E-ISSN 2250-2459, Scopus Indexed, ISO 9001:2008 Certified Journal, Volume 11, Issue 06, June 2021)

2. PT. XYZ Server. PT. XYZ will be connected directly to the database as a data archiving media. These messages are sent via the API by users involved in the system.

\section{Whatsapp Bot}

4. Whatsapp Bot users.

\section{B. Implementation and Performance}

Bots are made with the PHP programming language with the Laravel framework which is placed on the PT. XYZ server The bot module whatsapp webhook performs the function of receiving and sending messages with the help of a third-party Whatsapp API, in the webhook module it also contains a data communication function with the PT. $\mathrm{XYZ}$ system. The bot receives and sends messages through a webhook that is embedded on the PT. XYZ server and third-party API to each user every time there is a new message, Examples of the process of user communication with Bots can be seen in Figures 2 and 3.

After getting the response data from the user, the data will automatically be stored in the PT. XYZ is then used as a parameter for KPI calculation based on the type of aspects that have been determined as material for measuring Key Performance Indicators. The KPI measurements used in this case study are in Table 1.

In this case study, using the principle of "lower is better", meaning that the smaller the measurement results the better the driver's performance. The final results of the performance appraisal that uses the Key Performance Indicator to facilitate the Company's HRD in monitoring and marking the achievement of each driver's assessment, one of the methods used is to determine the standard range of assessments determined by PT. XYZ in table 2

The calculation results in Table 1 show the final score of one of the drivers getting a value of $\mathbf{6 . 2 5}$, which if mapped in the range of values is included in the predicate of value $\mathbf{B}$.

The other method has previously been carried out by Prasanna and Hemalatha [20] but they use RFID, GPS \& GSM in conducting research to monitor and track vehicle movements that are integrated with a microcontroller.
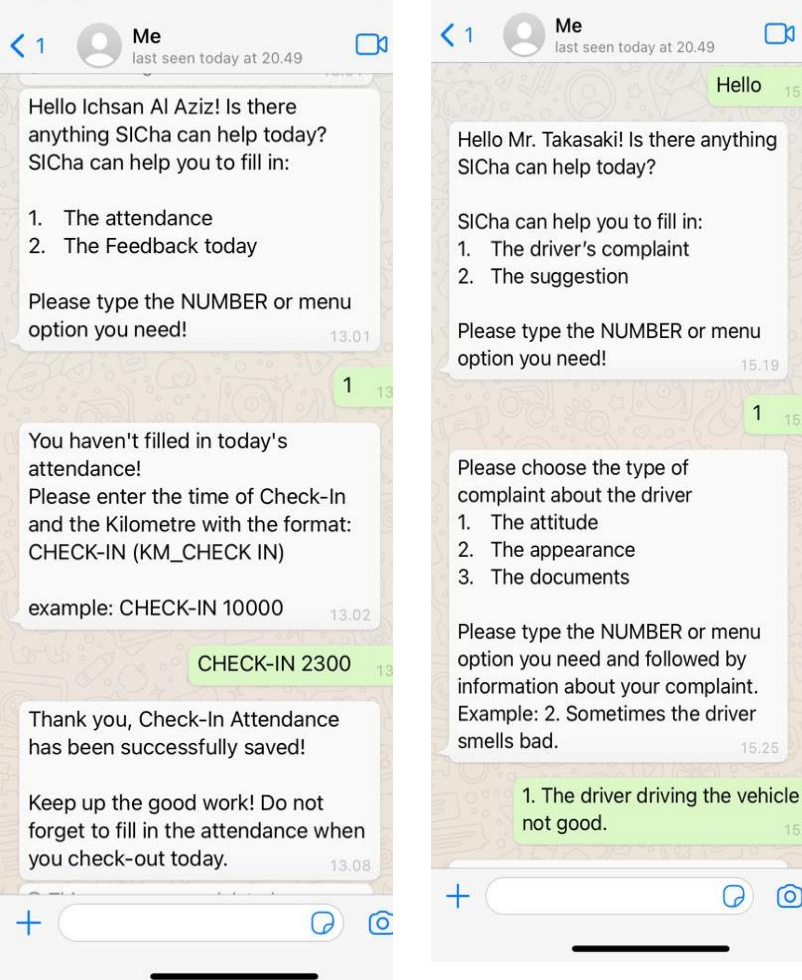

Hello Mr. Takasaki! Is there anything SICha can help today?

SICha can help you to fill in:

1. The driver's complaint

2. The suggestion

Please type the NUMBER or menu option you need!

Please choose the type of

complaint about the driver

1. The attitude

2. The appearance

3. The documents

Please type the NUMBER or menu option you need and followed by information about your complaint. Example: 2. Sometimes the driver smells bad.

1. The driver driving the vehicle not good.

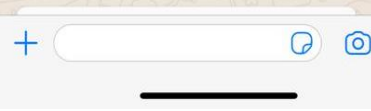

Figure 2. The process of communication driver with Bots
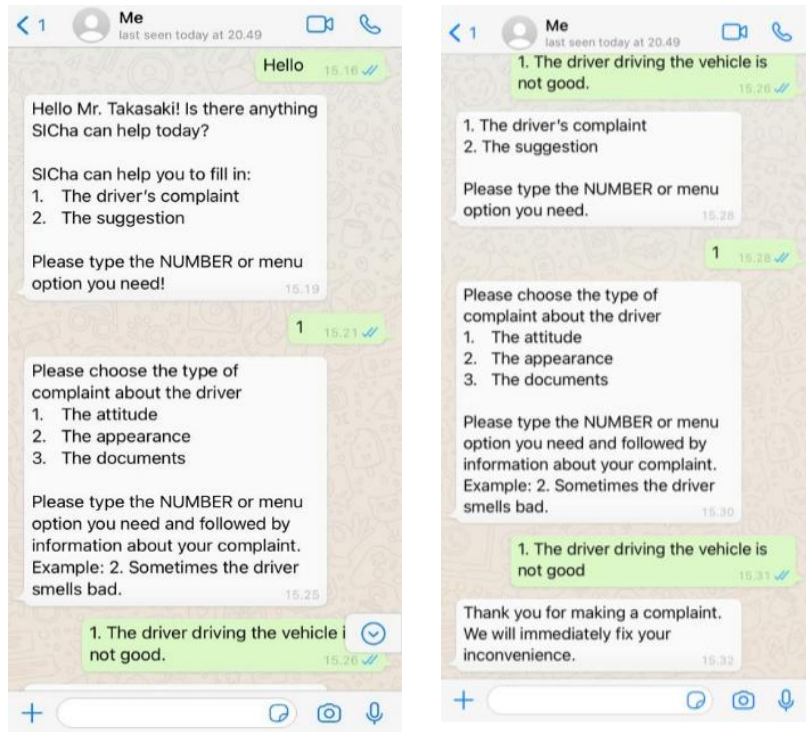

Figure 3. The process of communication client with Bot 


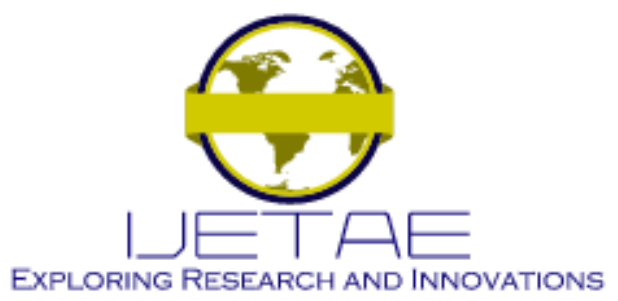

International Journal of Emerging Technology and Advanced Engineering

Website: www.ijetae.com (E-ISSN 2250-2459, Scopus Indexed, ISO 9001:2008 Certified Journal, Volume 11, Issue 06, June 2021)

Table I. Measuring table of Key Performance Indicators

\begin{tabular}{|c|c|c|c|c|c|}
\hline Key Target & Key Performance Indicator & Weight & $\begin{array}{c}\text { Realization } \\
\text { Amount per } \\
\text { period (30 } \\
\text { days) }\end{array}$ & Score & Final Score \\
\hline Attendance Aspect & driver delay or absence & 25 & 5 & $(5 / 30) * 100=17$ & $(17 * 25) / 100=4$ \\
\hline Behavioral Aspect & $\begin{array}{c}\text { complaints related to the } \\
\text { attitude of the driver }\end{array}$ & 25 & 1 & $(1 / 30) * 100=3$ & $(3 * 25) / 100=0.75$ \\
\hline Appearance Aspect & $\begin{array}{c}\text { complaints related to the } \\
\text { appearance of the driver }\end{array}$ & 25 & 1 & $(1 / 30) * 100=3$ & $(3 * 25) / 100=0.75$ \\
\hline Administrative aspect & $\begin{array}{c}\text { complaints related to } \\
\text { administrative requirements }\end{array}$ & 25 & 1 & $(1 / 30) * 100=3$ & $(3 * 25) / 100=0.75$ \\
\hline Total & & 100 & & & 6.25 \\
\hline
\end{tabular}

Table II.

Table of the standard range of assessment

\begin{tabular}{|c|c|}
\hline Score & Predicate \\
\hline $0-5$ & $\mathrm{~A}$ \\
\hline $5-10$ & $\mathrm{~B}$ \\
\hline $10-15$ & $\mathrm{C}$ \\
\hline $15-40$ & $\mathrm{D}$ \\
\hline $40-100$ & $\mathrm{E}$ \\
\hline
\end{tabular}

Triadi and Girsang [21] proposed a study using an android-based real time monitoring and tracking system to design KPI. It was based on tracking and monitoring of movement the logistics process using GPS \& GSM, because there are smartphones available with GPS at a fairly low cost compared to GPS Tracker.

\section{CONCLUSIONS}

This Whatsapp bot can be used as a media report on PT. $\mathrm{XYZ}$, security to access the PT. XYZ system via bot is guaranteed because Whatsapp numbers must match the data on the PT. XYZ system. The bot also makes it easy for users to interact with the PT. XYZ system. So that it is not difficult to report in real time, and PT. XYZ also makes it easier to conduct driver KPI assessments with data obtained from users, so they can make decisions to determine the extension of the driver's employment contract and rewards for drivers who work well.

The next research that can be done is to add the Natural Language Processing feature to the bot that is running. In addition, you can also add features from the finance department, for example, Bot can calculate overtime and send salary slips.

\section{REFERENCES}

[1] R. Nasrullah, Media Sosial: Persfektif Komunikasi, Budaya, dan Sosioteknologi, Bandung: Simbiosa Rekatama Media, 2015.

[2] R. Maria das Graas Bruno Marietto, Artificial intelligence markup language: A brief tutorial, 2013. 


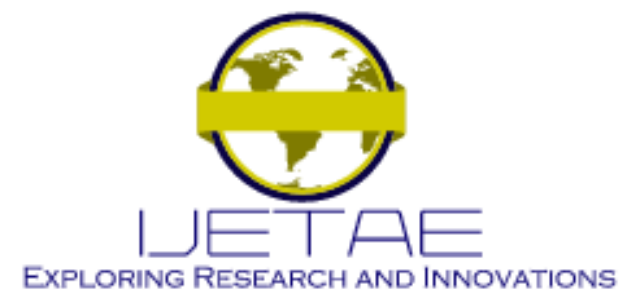

International Journal of Emerging Technology and Advanced Engineering Website: www.ijetae.com (E-ISSN 2250-2459, Scopus Indexed, ISO 9001:2008 Certified Journal, Volume 11, Issue 06, June 2021)

[3] Y. W. Chandraa and Suyanto, "Indonesian Chatbot of University Admission Using a Question Answering System Based on Sequenceto-Sequence Model," International Conference on Computer Science and Computational Intelligence, 2019.

[4] N. Ahmad and P. Orton, "Smartphones Make IBM Smarter, But Not As Expected," Technology and Development, 2010.

[5] D. Derks, D. Duin, M. Tims and A. Bakker, "Smartphone use and work-home interference: The moderating role of social norms and employee work engagement," Journal Occupation and Organization Psychology, 2014.

[6] A. Azfar, K. Choo and L. Liu, "An Android Communication App Forensic Taxonomy," Journal Forensic Science, 2017.

[7] C. Montag, K. Błaszkiewicz, R. Sariyska, B. Lachmann, I. Andone, B. Trendafilov, M. Eibes and A. Markowetz, "Smartphone usage in the 21st century: who is active on WhatsApp?," BMC Research, 2015.

[8] H. Meier, H. Lagemann, F. Morlock and C. Rathmann, "Key performance indicators for assessing the planning and delivery of industrial services.," 2013.

[9] B. N. Prastowo, N. A. Sulistyo Putro and A. Dhewa, "PLO User Interface based on Telegram Bot," Indonesian Journal of Computing and Cybernetics Systems, 2019.

[10] M. Badawy, A. Abd El-Aziz, A. M. Idress, H. Hefny and S. Hossam, "A survey on exploring key performance indicators," Future Computing and Informatics Journal, 2016.

[11] C. S. Warren, Accounting Indonesia Adaptation, Jakarta: Salemba Empat, 2014.

[12] G. Iveta, "Human Resources Key Performance Indicators.," Journal Of Competitiveness, 2012.
[13] K. P. Khalifa Mohamed, "Developing strategic health care key performance indicators: a case study on a tertiary care hospital.," 2015.

[14] N. Amalia Anza, Darwiyanto and A. W. Agung, "Analysis and Implementation of Employee Performance Measurement Application at PT. Sangkuriang Internasional Using the Balanced Scorecard Approach," e-Proceeding of Engineering, 2016.

[15] B. Travis, Check out the new AI-powered TechCrunch news bot on Telegram messenger, TechCrunch, 2016.

[16] J. Constine, Assist Has No App. It's A Free Travel/Shopping Chat Bot For SMS And Facebook Messenger, TechCrunch, 2016.

[17] A. Abashev, R. Grigoryev and K. Grigorian, "Programming Tools for Messenger- Based Chatbot System Organization: Implication for Outpatient and Translational Medicines," Bio Nano Science, 2017.

[18] Y. Nagender and K. H Patil, "Whatsapp Auto Responder Using Natural Language Processing And AI," International Journal of Computer Engineering \& Technology, 2017.

[19] J. Lockhart, Modern PHP : New Features and Good Practices, O'Reilly, Gravenstein Highway North, Sebastopol, USA, 2015, pp. $1-2$.

[20] K. R. Prasanna and M. Hemalatha, "RFID GPS and GSM based logistics vehicle load balancing and tracking mechanism," Procedia Eng., vol. 30, pp. 726-729, 2012.

[21] A. S. Girsang and T. Prabowo, "Monitoring system using GPS for logistic's key performance indicator,” Adv. Sci. Technol. Eng. Syst., vol. 4, no. 6, 2019, doi: 10.25046/aj040604. 